\title{
Pelet Bakteri Probiotik untuk Biokontrol Xanthomonas oryzae pv. oryzae dan Viabilitas Benih Padi
}

\author{
Probiotic Bacteria Pellet to Xanthomonas oryzae pv. oryzae \\ Biocontrol and Rice seed Viability
}

\author{
Anak Agung Keswari Krisnandika, Eny Widajati*, Wawan Hermawan, Giyanto \\ Institut Pertanian Bogor, Bogor 16680
}

\begin{abstract}
ABSTRAK
Bakteri probiotik yang berasal dari jaringan tanaman padi (endofit 467 dan endofit 748), rhizosfer (Ralstonia pickettii TT47), dan tanah (aktinomiset 6) diketahui mampu mengendalikan patogen penyebab penyakit. Pengaruh pelet yang mengandung bakteri probiotik dalam menekan patogen Xanthomonas oryzae pv. oryzae pada benih padi belum diketahui. Penelitian ini bertujuan menguji apakah pelet yang mengandung bakteri probiotik dapat mempertahankan viabilitas benih padi terinfeksi Xanthomonas oryzae pv. oryzae. Metode biakan ganda digunakan untuk menentukan kemampuan antagonis bakteri probiotik terhadap $X$. oryzae pv. oryzae. R. pickettii TT47, endofit 467 dan aktinomiset 6 terbukti antagonis terhadap $X$. oryzae pv. oryzae. Uji kompatibilitas bakteri probiotik menunjukkan isolat yang kompatibel ialah endofit 467 dan aktinomiset 6 . Aplikasi formula pelet (talk + CMC 1.5\% + gliserol 1\%) yang mengandung aktinomiset 6 tunggal atau kombinasi dengan endofit 467 pada benih padi Ciherang yang terinfeksi, mampu menekan populasi $X$. oryzae pv. oryzae pada 6 minggu penyimpanan. Perlakuan pelet yang mengandung $R$. pickettii TT47 mampu mempertahankan daya berkecambah dan kecepatan tumbuh benih padi terinfeksi $X$. oryzae pv. oryzae selama 6 minggu penyimpanan, masing-masing $86.67 \%$ dan $17.17 \%$ etmal $^{-1}$, berbeda nyata dengan benih terinfeksi yang tidak diberi perlakuan pelet $(62.67 \%$ dan $11.02 \%$ etmal $^{-1}$ ). Aplikasi bakteri probiotik R. pickettii TT47, endofit 467 atau aktinomiset 6 dalam bentuk pelet terbukti efektif menurunkan populasi patogen $X$. oryzae pv. oryzae dan mempertahankan viabilitas benih padi terinfeksi selama 6 minggu penyimpanan.
\end{abstract}

Kata kunci: aktinomiset, bakteri endofit, hawar daun bakteri, Ralstonia pickettii

\begin{abstract}
Probiotic bacteria collection from the rice plant tissue (i.e. endophytic 467 and endophytic 748 isolates), the rhizosphere (Ralstonia pickettii TT47) and that from the ground (actinomycetes 6) has been reported as biocontrol agents. The effect of pellet containing probiotic bacteria to suppress Xanthomonas oryzae pv. oryzae pathogen in rice seed has not been known thoroughly. This research was carried out to evaluate the effect of pellet containing probiotic bacteria in maintaining viability of rice seeds infected by $X$. oryzae pv. oryzae. A dual culture method was used to test the antagonistic activities between probiotic bacteria and $X$. oryzaepv. oryzae. Isolates $R$. pickettii TT47, endophytic 467 and actinomycetes 6 showed antagonistic activities against $X$. oryzae pv. oryzae. Among them, only endophytic 467 and actinomycetes 6 that showed compatibility. Pellet formulation (talc + CMC 1.5\% + glycerol 1\%) contain actinomycetes 6 singly or combination with endophytic 467 in infected Ciherang rice seed was able to suppress population $X$. oryzae pv. oryzae as long as 6 weeks storage. While, the highest percentage of

*Alamat penulis korespondensi: Departemen Agronomi dan Hortikultura, Fakultas Pertanian, Institut Pertanian Bogor, Kampus Darmaga, Jalan Meranti, Bogor 16680

Tel: 0251-8629350,Faks: 0251-8629352,Surel: eny_widajati@yahoo.co.id.
\end{abstract}


seed germination and seedling growth rate during 6 weeks storage was obtained on pellet formulation with $R$. pickettii TT47, i.e. $86.67 \%$ and $17.17 \%$ etmal $^{-1}$ respectively and significantly different with infected nonpelleted rice seed $\left(62.67 \%\right.$ and $11.02 \%$ etmal $\left.^{-1}\right)$. In conclusion, the application of probiotic bacteria $R$. pickettii TT47, endophytic 467 and actinomycetes 6 in pellet formulation was effective to decrease $X$. oryzae pv. oryzae and maintain viability of infected rice seed in 6 weeks storage.

Key words: actinomycetes, endophytic, rice sheath blight, Ralstonia pickettii

\section{PENDAHULUAN}

Xanthomonas oryzae pv. oryzae menginfeksi pertanaman padi mulai dari fase bibit (penyakit kresek) sampai menjelang panen (penyakit hawar daun bakteri). Penurunan hasil hingga $70 \%$ dapat terjadi pada padi varietas rentan (IRRI 2014). Pada tahun 20092013 sekitar 27.6 ha lahan pertanaman padi di Indonesia mengalami puso dari total 94246 ha lahan yang terserang hawar daun bakteri (HDB) (Ditlitanpang 2014).

Pengendalian $X$. oryzae pv. oryzae umumnya menggunakan bakterisida sintetik, namun teknik ini dinilai kurang ramah lingkungan. Oleh sebab itu, pengendalian $X$. oryzae pv. oryzae secara biologi menggunakan bakteri probiotik mulai dikembangkan.

Bakteri kelompok Bacillus, Pseudomonas dan Streptomyces diketahui mampu menekan $X$. oryzae pv. oryzae dengan menghasilkan antibiotik (difficidin, bacilysin, iturin), siredofor, HCN, maupun hormon pertumbuhan (indole acetic acid; IAA) (Miliute dan Buzaite 2011; Beric et al. 2012; Lukkani dan Reddy 2014; Harikrishnan et al. 2014; Wu et al. 2015). Pemanfaatan B. subtilis dengan merendam benih padi terinfeksi terbukti mampu menurunkan populasi $X$. oryzae pv. oryzae serta meningkatkan pertumbuhan bibit padi (Agustiansyah et al.2010).

Sulitnya menyediakan inokulum bakteri aktif dalam jumlah banyak di lapangan merupakan salah satu masalah pemanfaatan bakteri probiotik. Upaya alternatif yang dapat dilakukan ialah aplikasi bakteri langsung pada benih dalam bentuk formula kering (pelet). Pelet yang baik mampu melindungi benih dan bakteri dari kondisi ekstrem ketika di penyimpanan, transportasi dan aplikasi dilapangan.
Pelet terdiri atas bahan pembawa, perekat, dan inokulan. Bahan pembawa dan perekat yang baik mempertahankan viabilitas benih padi ialah campuran CMC $1.5 \%$ dan talk $1 \%$ (Palupi et al. 2012). Perlakuan benih padi dengan formula tersebut dapat mempertahankan viabilitas bakteri $P$. flourescens RRb-11 hingga 90 hari $\left(30.1 \times 10^{7} \mathrm{cfu} \mathrm{g}^{-1}\right)$ serta efektif mereduksi keparahan penyakit HDB sampai 83.87\% (Jambhulkar dan Sharma 2014).

Informasi pemanfaatan bakteri probiotik dalam formula pelet dan pengaruhnya terhadap viabilitas benih padi yang terinfeksi $X$. oryzae pv. oryzae belum tersedia. Oleh sebab itu, penelitian ini bertujuan mengevaluasi kemampuan pelet yang mengandung bakteri probiotik dalam menekan patogen $X$. oryzae pv. oryzae dan mempertahankan viabilitas benih padi terinfeksi.

\section{BAHAN DAN METODE}

Benih padi yang digunakan adalah padi varietas Ciherang yang diproduksi PT. Sang Hyang Seri, Indonesia. Bakteri probiotik Ralstonia pickettii TT47, endofit 467, endofit 748 dan aktinomiset 6 diperoleh dari Laboratorium Bakteriologi Tumbuhan, Departemen Proteksi Tanaman, IPB. Bakteri patogen (X. oryzae pv. oryzae patotipe IV) berasal dari Balai Besar Tanaman Padi Sukamandi.

\section{Uji Antagonis}

Uji antagonis 4 isolat bakteri probiotik terhadap patogen $X$. oryzae $\mathrm{pv}$. oryzae dilakukan menggunakan metode biakan ganda (Putra dan Giyanto 2014). Medium yang digunakan adalah yeast dextrose carbon agar (YDCA), inkubasi dilakukan selama 3-5 hari pada suhu ruang. Pengamatan 
terhadap ada tidaknya zona bening di sekitar kertas saring dilakukan setiap hari. Zona bening menunjukkan bakteri probiotik pada kertas saring menghasilkan senyawa yang bersifat antagonis terhadap $X$. oryzae $\mathrm{pv}$. oryzae yang berada pada medium YDCA.

\section{Uji Kompatibilitas}

Uji kompatibilitas bakteri probiotik $R$. pickettii TT47, endofit 467, endofit 748, dan aktinomiset 6 dilakukan menggunakan metode biakan ganda (Putra dan Giyanto 2014) pada medium nutrient agar (NA).

Pelet dengan Penambahan Bakteri Probiotik pada Benih Padi yang Diinfeksi X. oryzae pv. oryzae

Benih padi diinfeksi $X$. oryzae pv. oryzae terlebih dahulu menggunakan metode Agustiansyah et al. (2010). Benih terinfeksi kemudian diberi perlakuan pelet secara manual menggunakan formula talk + CMC $1.5 \%+$ gliserol $1 \%+$ bakteri probiotik $\left(10^{8}-\right.$ $\left.10^{9} \mathrm{cfu} \mathrm{mL}^{-1}\right)$. Talk komersil disterilisasi menggunakan autoklaf terlebih dahulu sebelum digunakan. Perbandingan formula pelet dengan benih padi adalah 5:0.6 (b/b).

Percobaan disusun menggunakan rancangan acak kelompok petak tersarang dengan 3 ulangan. Petak utama adalah periode simpan (0, 2, 4, 6 minggu). Anak petak adalah 8 taraf perlakuan pelet, yaitu: K (benih sehat), $X$. oryzae pv. oryzae (Xoo), benih direndam dalam air selama 24 jam pada suhu ruang, $\mathrm{K}$ + pelet, Xoo + pelet + aktinomiset $6+$ endofit $467, \mathrm{Xoo}+$ pelet + aktinomiset $6, \mathrm{Xoo}+$ pelet + endofit 467, dan Xoo+ pelet $+R$. pickettii TT47. Pengeringan benih dilakukan 2-3 hari dalam kondisi ruang. Pengamatan dilakukan terhadap populasi $X$. oryzae $p v$. oryzae pada perlakuan benih 0, 2, 4 dan 6 minggu sesuai metode yang dijabarkan Putra dan Giyanto (2014). Viabilitas benih diduga berdasarkan daya berkecambah (DB) dan kecepatan tumbuh $\left(\mathrm{K}_{\mathrm{CT}}\right)$ yang dihitung berdasarkan akumulasi $\mathrm{K}_{\mathrm{CT}}$ harian dalam unit tolok ukur persentase per hari ( 24 jam $=1$ etmal $)$.

$$
\begin{gathered}
\mathrm{DB}=\frac{\sum \mathrm{K}_{\mathrm{N} \text { hitungan I }}+\sum \mathrm{K}_{\mathrm{N} \mathrm{hitungan} \mathrm{II}}}{\sum \mathrm{B}_{\mathrm{T}}} \times 100 \% \\
\mathrm{~K}_{\mathrm{CT}}=\frac{\% \mathrm{~K}_{\mathrm{N} \mathrm{ke-2}}+\ldots . .+\frac{\% \mathrm{~K}_{\mathrm{N} \mathrm{ke-n}}}{\text { etmal }}}{\text { etmal }} \text {, dengan }
\end{gathered}
$$

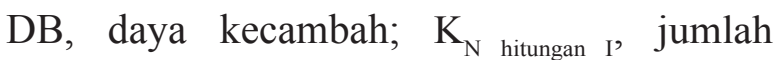

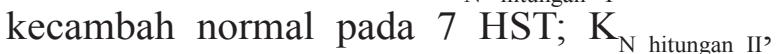
jumlah kecambah normal pada 14 HST; $\mathrm{BT}$, jumlah benih yang ditanam dan; $\mathrm{K}_{\mathrm{CT}}$, kecepatan tumbuh.

Data diolah menggunakan analisis sidik ragam (ANOVA) pada program SAS dilanjutkan uji DMRT pada taraf kepercayaan 95\%.

\section{HASIL}

\section{Aktivitas Antagonis}

Bakteri probiotik $R$. pickettii TT47 menghasilkan zona bening terbesar di sekitar kertas saring steril, diikuti oleh aktinomiset 6 dan endofit 467, sedangkan endofit 748 tidak menghasilkan zona bening.

\section{Kompatibilitas Bakteri Probiotik}

Bakteri probiotik aktinomiset 6 dan endofit 467 menunjukkan sifat kompatibilitas (Tabel 1). Isolat endofit 748 tidak bersifat antagonis terhadap $X$. oryzae pv. oryzae dan tidak kompatibel dengan 3 isolat bakteri probiotik lain yang diuji sehingga tidak digunakan untuk uji lanjut.

Tabel 1 Kompatibilitas bakteri probiotik ditandai dengan pembentukan zona bening di sekitar kertas saring steril pada medium nutrient agar selama 3-5 hari inkubasi

\begin{tabular}{lcccc}
\hline Bakteri probiotik & Endofit 467 & Endofit 748 & Aktinomiset 6 & R. pickettii TT47 \\
\hline Endofit 467 & $\mathrm{x}$ & - & - & + \\
Endofit 748 & + & $\mathrm{x}$ & - & + \\
Aktinomiset 6 & - & + & $\mathrm{x}$ & + \\
Ralstonia pickettii TT47 & + & - & - & $\mathrm{x}$ \\
\hline
\end{tabular}

+, terbentuk zona bening; -, tidak terbentuk zona bening; $x$, tidak diuji kompatibilitas 


\section{Viabilitas Benih Padi}

Pelet yang mengandung aktinomiset 6 tunggal maupun kombinasi dengan endofit 467 efektif dalam menekan patogen $X$. oryzae pv. oryzae pada benih padi terinfeksi selama 6 minggu simpan (Tabel 2). Pelet yang mengandung $R$. pickettii TT47 paling baik dalam mempertahankan viabilitas benih terinfeksi (Tabel 3 dan 4) ditunjukkan oleh DB $(86.67 \%)$ dan $\mathrm{K}_{\mathrm{CT}}\left(17.17 \%\right.$ etmal $\left.^{-1}\right)$ yang nyata lebih tinggi dibandingkan dengan benih terinfeksi $X$. oryzae pv. oryzae $(62.67 \%$ dan $11.02 \%$ etmal $\left.^{-1}\right)$.

\section{PEMBAHASAN}

Pengendalian patogen terbawa benih $X$. oryzae pv. oryzae menggunakan agens antagonis seperti bakteri probiotik merupakan alternatif yang potensial dan ramah lingkungan. Pada penelitian ini, bakteri $R$. pickettii TT47 mampu menghasilkan senyawa antagonis yang lebih banyak dibandingkan endofit 467 dan aktinomiset 6 secara in vitro, namun dalam formulasi pelet pada benih padi terinfeksi $X$. oryzae pv. oryzae, aktinomiset 6 tunggal maupun kombinasi dengan endofit 467 lebih efektif menekan perkembangan $X$. oryzae pv. oryzae. Hal ini diduga karena aktinomiset dan endofit merupakan bakteri Gram positif yang menghasilkan spora toleran kering dan panas (Emmert dan Handelsman 1999) sehingga mampu bertahan dalam formula pelet dengan lebih baik dibandingkan dengan $R$. pickettii TT47 yang tidak memiliki sruktur bertahan.

Penghambatan patogen $X$. oryzae pv. oryzae oleh bakteri probiotik $R$. pickettii TT47 diduga terkait dengan kemampuan bakteri

Tabel 2 Perlakuan benih terhadap populasi patogen $X$. oryzae pv. oryzae dalam benih padi pada setiap periode simpan (minggu)

\begin{tabular}{lcccc}
\hline \multirow{2}{*}{ Perlakuan } & \multicolumn{4}{c}{ Populasi patogen selama periode simpan } \\
\cline { 2 - 5 } & 0 & 2 & 4 & 6 \\
\hline Xoo + Pelet + Aktinomiset 6 + Endofit 467 & $4.65 \mathrm{bc}$ & $4.63 \mathrm{bc}$ & $4.68 \mathrm{bc}$ & $1.00 \mathrm{e}$ \\
Xoo + Pelet + Aktinomiset 6 & $4.52 \mathrm{bc}$ & $4.85 \mathrm{bc}$ & $4.68 \mathrm{bc}$ & $1.00 \mathrm{e}$ \\
Xoo + Pelet + Endofit 467 & $4.15 \mathrm{c}$ & $4.51 \mathrm{bc}$ & $4.56 \mathrm{bc}$ & $2.52 \mathrm{~d}$ \\
Benih sehat (K) & $1.00 \mathrm{e}$ & $1.00 \mathrm{e}$ & $1.00 \mathrm{e}$ & $1.00 \mathrm{e}$ \\
Benih direndam air & $1.00 \mathrm{e}$ & $1.00 \mathrm{e}$ & $1.00 \mathrm{e}$ & $1.00 \mathrm{e}$ \\
K + Pelet & $1.00 \mathrm{e}$ & $1.00 \mathrm{e}$ & $1.00 \mathrm{e}$ & $1.00 \mathrm{e}$ \\
X + Pelet + Ralstonia pickettii TT47 & $4.53 \mathrm{c}$ & $4.34 \mathrm{c}$ & $4.48 \mathrm{c}$ & $4.18 \mathrm{c}$ \\
X. oryzae pv. oryzae (Xoo) & $5.72 \mathrm{ab}$ & $6.02 \mathrm{a}$ & $6.19 \mathrm{a}$ & $6.67 \mathrm{a}$ \\
\hline
\end{tabular}

Angka yang diikuti huruf yang sama tidak berbeda nyata pada DMRT pada $\alpha$ 5\%

Data yang digunakan adalah hasil transformasi $\log (\mathrm{x}+10)$; Pelet terdiri atas talk + CMC 1.5\% + gliserol 1\%

Tabel 3 Perlakuan benih padi terhadap daya berkecambah pada setiap periode simpan (minggu)

\begin{tabular}{llccc}
\hline \multirow{2}{*}{ Perlakuan } & \multicolumn{4}{c}{ Daya kecambah pada periodesimpan (\%) } \\
\cline { 2 - 5 } & 0 & 2 & 4 & 6 \\
\hline Xoo + Pelet + Aktinomiset 6 + Endofit 467 & $92.00 \mathrm{a}$ & $84.00 \mathrm{abc}$ & $82.67 \mathrm{abc}$ & $82.67 \mathrm{abc}$ \\
Xoo + Pelet + Aktinomiset 6 & $90.67 \mathrm{a}$ & $86.67 \mathrm{abc}$ & $84.00 \mathrm{abc}$ & $84.00 \mathrm{abc}$ \\
Xoo + Pelet + Endofit 467 & $90.67 \mathrm{a}$ & $64.00 \mathrm{de}$ & $76.00 \mathrm{bcd}$ & $73.33 \mathrm{dec}$ \\
Benih sehat (K) & $92.00 \mathrm{a}$ & $82.67 \mathrm{abc}$ & $84.00 \mathrm{abc}$ & $94.67 \mathrm{a}$ \\
Benih direndam air & $89.33 \mathrm{ab}$ & $85.33 \mathrm{abc}$ & $86.67 \mathrm{abc}$ & $94.67 \mathrm{a}$ \\
K + Pelet & $93.33 \mathrm{a}$ & $85.33 \mathrm{abc}$ & $89.33 \mathrm{ab}$ & $90.67 \mathrm{a}$ \\
X + Pelet + Ralstonia pickettii TT47 & $90.67 \mathrm{a}$ & $84.00 \mathrm{abc}$ & $89.33 \mathrm{ab}$ & $86.67 \mathrm{abc}$ \\
X. oryzae pv. oryzae (Xoo) & $89.33 \mathrm{ab}$ & $86.67 \mathrm{abc}$ & $80.00 \mathrm{abc}$ & $62.67 \mathrm{e}$ \\
\hline
\end{tabular}

Angka yang diikuti huruf yang sama tidak berbeda nyata pada DMRT pada $\alpha$ 5\%

Pelet terdiri atas talk + CMC $1.5 \%+$ gliserol $1 \%$ 
Tabel 4 Perlakuan benih terhadap kecepatan tumbuh padi pada setiap periode simpan (minggu)

\begin{tabular}{lllll}
\hline \multirow{2}{*}{ Perlakuan } & \multicolumn{4}{c}{ Kecepatan pertumbuhan benih padi $\left(\%\right.$ etmal $\left.^{-1}\right)$} \\
\cline { 2 - 5 } & \multicolumn{1}{c}{0} & \multicolumn{1}{c}{2} & \multicolumn{1}{c}{4} & 6 \\
\hline Xoo + Pelet + Aktinomiset 6 + Endofit 467 & $16.01 \mathrm{fgh}$ & $16.81 \mathrm{e}-\mathrm{h}$ & $16.01 \mathrm{fgh}$ & $16.04 \mathrm{fgh}$ \\
Xoo + Pelet + Aktinomiset 6 & $15.76 \mathrm{gh}$ & $17.07 \mathrm{c}-\mathrm{h}$ & $15.13 \mathrm{~h}$ & $15.73 \mathrm{gh}$ \\
Xoo + Pelet + Endofit 467 & $15.11 \mathrm{~h}$ & $12.06 \mathrm{i}$ & $15.11 \mathrm{~h}$ & $11.44 \mathrm{i}$ \\
Benih sehat (K) & $18.84 \mathrm{a}-\mathrm{g}$ & $16.92 \mathrm{~d}-\mathrm{h}$ & $18.84 \mathrm{a}-\mathrm{g}$ & $19.15 \mathrm{a}-\mathrm{f}$ \\
Benih direndam air & $19.28 \mathrm{a}-\mathrm{e}$ & $20.10 \mathrm{a}-\mathrm{c}$ & $19.28 \mathrm{ab}$ & $20.88 \mathrm{a}$ \\
K + Pelet & $20.35 \mathrm{ab}$ & $20.46 \mathrm{ab}$ & $20.35 \mathrm{ab}$ & $20.03 \mathrm{a}-\mathrm{d}$ \\
X + Pelet + Ralstonia pickettii TT47 & $17.04 \mathrm{c}-\mathrm{h}$ & $17.60 \mathrm{~b}-\mathrm{h}$ & $17.04 \mathrm{c}-\mathrm{h}$ & $17.17 \mathrm{c}-\mathrm{h}$ \\
X. oryzae pv. oryzae (Xoo) & $15.24 \mathrm{~h}$ & $16.84 \mathrm{e}-\mathrm{h}$ & $15.24 \mathrm{~h}$ & $11.02 \mathrm{i}$ \\
\hline
\end{tabular}

Angka yang diikuti huruf yang sama tidak berbeda nyata pada DMRT pada $\alpha$ 5\%

Pelet terdiri atas talc $+\mathrm{CMC} 1.5 \%+$ gliserol 1\%. 1 etmal $=24$ jam.

ini dalam menghasilkan siderofor (Rustam 2012). Siderofor mampu mengikat zat besi (Crosa dan Walsh 2002) di medium sehingga tidak tersedia untuk $X$. oryzae pv. oryzae. Mikrob dalam kondisi aerob membutuhkan zat besi untuk berbagai siklus dalam sel (Skaar 2010). Beragam senyawa aktif yang dihasilkan bakteri probiotik untuk menekan perkembangan $X$. oryzae pv. oryzae, yaitu bottromycin $\mathrm{A} 2$ dan dunaimycin $\mathrm{D} 3 \mathrm{~S}$, yang dihasilkan oleh Streptomyces bottropensis (Park et al. 2011), 2.4-diacetylphloroglucinol (DAPG) oleh Pseudomonas fluorescens PDY7 (Velusamy et al. 2013), kitinase, fosfatase dan siredofor dari Streptomyces sp. (AB131-1 dan LBR02) (Hastuti et al. 2012) serta produksi siderofor, enzim fosfatase, enzim peroksidase dan HCN oleh P. diminuta A6 (Agustiansyah et al. 2013).

Pelet yang mengandung bakteri probiotik mampu mempertahankan viabilitas benih padi terinfeksi $X$. oryzae pv. oryzae. Hal ini diduga terkait dengan keamampuan bakteri dalam menekan patogen $X$. oryzae pv. oryzae dan atau menghasilkan hormon pertumbuhan. Bakteri probiotik seperti aktinomiset, endofit, dan $R$. pickettii dilaporkan mampu menghasilkan hormon pertumbuhan seperti IAAdan giberelin (Lestari et al. 2014). Giberelin menginduksi sintesis enzim $\alpha$-amilase yang berperan dalam perombakan pati untuk digunakan sebagai energi dalam perkecambahan benih (Palmiano dan Juliano 1972). Hormon IAA dibutuhkan tanaman setelah berkecambah untuk perpanjangan sel (Miransari dan Smith 2014).
Subash et al. (2015) menyatakan aplikasi $2 \mathrm{mg} \mathrm{L}^{-1}$ GA3 dan IAA pada benih Sesamum indicum TVM-1 mampu meningkatkan perkecambahan, panjang akar dan tunas. Chithrashree et al. (2011) melaporkan perlakuan benih menggunakan talk + CMC $(0.2 \%)+$ Bacillus sp. mampu secara nyata meningkatkan perkecambahan $(82 \%)$ dan vigor indeks (1309) benih padi terinfeksi $X$. oryzae pv. oryzae.

Perlakuan pelet yang mengandung endofit 467, aktinomiset $6, R$. pickettii TT47 maupun aktinomiset $6+$ endofit 467 terbukti efektif menekan patogen $X$. oryzae pv. oryzae dan mempertahankan viabilitas benih padi terinfeksi selama 6 minggu penyimpanan.

\section{UCAPAN TERIMA KASIH}

Penulis menyampaikan terima kasih kepada Ditjen DIKTI yang telah memberikan dana pendidikan dan penelitian melalui Beasiswa Pendidikan Pascasarjana Dalam Negeri (BPPDN) serta Balai Besar Penelitian Padi Sukamandi sebagai pemilik isolat $X$. oryzae pv. oryzae.

\section{DAFTAR PUSTAKA}

Agustiansyah, Ilyas S, Sudarsono, Machmud M. 2010. Pengaruh perlakuan benih secara hayati pada benih padi terinfeksi Xanthomonas oryzae pv. oryzae terhadap mutu benih dan pertumbuhan bibit. J Agron Indonesia. 38:185-191. 
Agustiansyah, Ilyas S, Sudarsono, Machmud M. 2013. Karakterisasi rizobakteri yang berpotensi mengendalikan bakteri Xanthomonas oryzae pv. oryzae dan meningkatkan pertumbuhan tanaman padi. J HPT Tropika. (13)1:42-51.

Beric T, Kojic M, Stankovic S, Topisirovic L, Degrassi G, Myers M, Venturi V, Fira D. 2012. Antimicrobial activity of Bacillus sp. natural isolates and their potential use in the biocontrol of phytopathogenic bacteria. Food Technol Biotechnol. 50(1):25-31.

Chithrashree AC. Udayashankar, Nayaka SC, Reddy MS, Srinivas C. 2011. Plant growth-promoting rhizobacteria mediate induced systemic resistance in rice against bacterial leaf blight caused by Xanthomonas oryzae pv. oryzae. Bio Control. 59:114-122. DOI: http://dx.doi. org/10.1016/j.biocontrol.2011.06.010.

Crosa JH, Walsh CT. 2002. Genetics and assembly line enzymology of siderophore biosynthesis in bacteria. Microbiol Mol Biol Rev. 66:223-249. DOI: http://dx.doi. org/10.1128/MMBR.66.2.223-249.2002.

[Ditlitanpang] Direktorat Perlindungan Tanaman Pangan. 2014. Data OPT padi. http://tanamanpangan.pertanian. go.id/ditlintp/statis-17-dataoptpadi.html [diakses 2 Maret 2014].

Emmert EAB, Handelsman J. 1999. Biocontrol of plant disease: a (Gram-) positive perspective. FEMS Microbiol Lett. 171:1-9. DOI: http://dx.doi. org/10.1111/j.1574-6968.1999.tb13405.x.

Harikrishnan H, Shanmugaiah V, Balasubramanian N. 2014. Optimization for production of Indole acetic acid (IAA) by plant growth promoting Streptomyces sp VSMGT1014 isolated from rice rhizosphere. Int J Curr Microbiol App Sci. 3(8):158-171.

Hastuti, R.D., Y. Lestari, A. Suwanto, R. Saraswati. 2012. Endophytic Streptomyces spp. as biocontrol agents of rice bacterial leaf blight pathogen. Hayati J Biosci. 19(4):155-162. DOI: http://dx.doi. org/10.4308/hjb.19.4.155.
[IRRI] International Rice Research Institute. 2014. Bacterial blight. http://www. knowledgebank.irri.org/decision-tools/ rice-doctor/rice-doctor-factsheets/item/ bacterial-blight [diakses 2 Maret 2014].

Jambhulkar PP, Sharma P. 2014. Development of bioformulation and delivery system of Pseudomonas fluorescens against bacterial leaf blight of rice (Xanthomonas oryzae pv. oryzae). JEB. 35:843-849.

Lestari Y, Yusepi TT, Pratyasto AP, Mubarik NR, Hamim. 2014. In vitro capability of rice endophytic Streptomyces spp. in producing indole acetic acid and fixing nitrogen. Adv Environ Biol. 8(13):728-735. Lukkani NJ, Reddy ECS. 2014. Evaluation of plant growth promoting attributes and biocontrol potential of native fluorescent Pseudomonas spp. against Aspergillus niger causing collar rot of ground nut. IJPAES. 4(4):256-262.

Miliute I, Buzaite O. 2011. IAA production and other plant growth promoting traits of endophytic bacteria from apple tree. Biologija. 57(2):98-102. DOI: http:// dx.doi.org/10.6001/biologija.v57i2.1835.

Miransari M, Smith DL. 2014. Plant hormones and seed germination. Environ Eexp Bot. 99:110-121. DOI: http://dx.doi. org/10.1016/j.envexpbot.2013.11.005.

Palmiano EP, Juliano BO. 1972. Biochemical changes in the rice grain during germination. Plant Physiol. 49:751-756. DOI: http:// dx.doi.org/10.1104/pp.49.5.751.

Palupi T, Ilyas S, Machmud M, Widajati E. 2012. Pengaruh formula coating terhadap viabilitas dan vigor serta daya simpan benih padi (Oryza sativa L.). J Agron Indonesia. 40(1):21-28.

Park SB, Lee IA, Suh JW, Kim JG, Lee CH. 2011. Screening and identification of antimicrobial compounds from Streptomyces bottropensis suppressing rice bacterial blight. J Microbiol Biotechnol. 21(12):1236-1242. DOI: http://dx.doi. org/10.4014/jmb.1106.06047.

Putra C, Giyanto. 2014. Kompatibilitas Bacillus spp. dan aktinomiset sebagai agens 
hayati Xanthomonas oryzae pv. oryzae dan pemacu pertumbuhan padi. 2014. J Fitopatol Indones. 10(5):160-169. DOI: http://dx.doi.org/10.14692/jfi.10.5.160.

Rustam. 2012. Potensi bakteri penghasil senyawa bioaktif anticendawan untuk pengendalian penyakit hawar pelepah padi [tesis]. Bogor (ID): Institut Pertanian Bogor.

Skaar EP. 2010. The battle for iron between bacterial pathogens and their vertebrate hosts. PLoS Pathog. 6(8):1-4. DOI: http:// dx.doi.org/10.1371/journal.ppat.1000949.

Subash M, Rafath H, Lalitha J. 2015. Influence of GA3 and IAA and their frequency of application on seed germination and seedling quality characters. Int Lett
Nat Sci. 30:44-48. DOI: http://dx.doi. org/10.18052/www.scipress.com/ ILNS.30.44.

Velusamy P, Immanuel JE, Gnanamanickam SS. 2013. Rhizosphere bacteria for biocontrol of bacterial blight and growth promotion of rice. Rice Sci. 20(5):356362. DOI: http://dx.doi.org/10.1016/ S1672-6308(13)60143-2.

Wu L, Wu H, Chen L, Yu X, Borriss R, Gao X. 2015. Difficidin and bacilysin from Bacillus amyloliquefaciens FZB42 have antibacterial activity against Xanthomonas oryzae rice pathogens. Scientific Reports. 5(12975):1-9. DOI: http://dx.doi. org/10.1038/srep12975. 